\title{
Native and Recombinant Proguanylin Feature Identical Biophysical Properties and Are Monomeric in Solution ${ }^{\dagger}$
}

\author{
Thomas Lauber, ${ }^{\ddagger}$ Amanda Nourse, ${ }^{\S}$ Axel Schulz,, and Ute C. Marx ${ }^{*, \sharp}$ \\ Lehrstuhl für Biopolymere, Universität Bayreuth, Universitätstrasse 30, 95447 Bayreuth, Germany, Institute for Molecular \\ Bioscience and Australian Research Council Special Research Centre for Functional and Applied Genomics, \\ University of Queensland, Brisbane, Queensland 4072, Australia, and IPF PharmaCeuticals GmbH, \\ Feodor-Lynen-Strasse 31, 30625 Hannover, Germany
}

Received July 11, 2002; Revised Manuscript Received September 20, 2002

\begin{abstract}
Guanylin, an intestinal peptide hormone and endogenous ligand of guanylyl cyclase C, is produced as the corresponding prohormone proguanylin. The mature hormone consists of 15 amino acid residues, representing the $\mathrm{COOH}$-terminal part of the prohormone comprised of 94 amino acid residues. Here we report the recombinant expression and purification of proguanylin with its native disulfide connectivity, as well as the biophysical characterization of the recombinant and native protein. The comparison of recombinant and native proguanylin revealed identical biophysical and structural properties, as deduced from CZE, HPLC, and mass spectrometry, as well as NMR spectroscopy and CD spectroscopy at various temperatures and $\mathrm{pH}$ values. Exhaustive analytical ultracentrifugation studies were employed for protein concentrations up to the millimolar range to determine the association state of recombinant as well as native proguanylin, revealing both proteins to be monomeric at the applied solution conditions. As a result, a former identified close proximity between the termini of proguanylin is due to intramolecular interactions.
\end{abstract}

The intestinal peptide hormone guanylin is an endogenous activator of guanylyl cyclase C (1). Activation of the cyclase markedly increases secretion of fluid and electrolytes into the intestinal lumen (2) by cGMP-mediated activation of the cystic fibrosis transmembrane conductance regulator (CFTR) $(3,4)$. For bioactivity, formation of the correct $1-3,2-4$ disulfide bonds of guanylin is necessary $(1,5)$. Even though guanylin possesses a unique cysteine connectivity, it is able to form two interconverting topological stereoisomers (6), with only one of them (A-form) showing significant biological effects (7).

Guanylin is expressed as the corresponding prohormone containing 94 amino acid residues, with the mature hormone [guanylin-(80-94); numbering is according to the sequence of the prohormone] located at its $\mathrm{COOH}$ terminus, and is secreted into the intestinal mucosa and blood $(8,9)$. It has been shown that an essential contribution of the prosequences of guanylin and the closely related uroguanylin is in the disulfide-coupled folding $(10,11)$. The prohormone, however, only shows negligible guanylyl cyclase $\mathrm{C}$ activating potency $(10,12)$. As an explanation for the inactivation of the bioactive $\mathrm{COOH}$-terminal part of proguanylin, a shielding by its $\mathrm{NH}_{2}$ terminus was suggested, since a close proximity of the $\mathrm{NH}_{2}$ - and $\mathrm{COOH}$-terminal regions of proguanylin was

\footnotetext{
This study was funded by the Deutsche Forschungsgemeinschaft (DFG) (project MA2317-1), as well as by the Bayerischer Habilitationsförderpreis to U.C.M.

* Corresponding author. Phone: ++49 921 552048. Fax: ++49

921 553544. E-mail: Ute.Marx@uni-bayreuth.de.

サniversität Bayreuth.

$\S$ University of Queensland.

"IPF PharmaCeuticals GmbH.
}

found (10). Since prouroguanylin and proguanylin show unusual elution behavior in size exclusion chromatography, they were assumed to be dimeric in solution (13). Nonetheless, no variation of the oligomerization state of native proguanylin was observed over the concentration range from 0.24 to $2.4 \mathrm{mM}(10)$. As reversible association is concentration dependent, this result favors a monomeric state, but a very tight dimer cannot be excluded. An accurate determination of the oligomerization state, however, is a requirement for the correct interpretation of the available and further structural and biological data.

For further functional studies of the role of the prosequence of guanylin-(80-94) in the proper folding of the prohormone and for the elucidation of the mechanism of inactivation of the $\mathrm{COOH}$-terminal portion on a molecular level, structure determination of proguanylin is a requisite. Therefore, an efficient expression system for the production of proguanylin is required. In this work, we present a new strategy for the recombinant expression and purification of proguanylin, leading to a soluble protein possessing the native disulfide connectivity. Comparison of recombinant and native proguanylin revealed identical biophysical behavior as deduced from CZE, ${ }^{1}$ HPLC, and mass spectrometry. Furthermore,

${ }^{1}$ Abbreviations: BCA, bicinchoninic acid; $\mathrm{CD}$, circular dichroism; CZE, capillary zone electrophoresis; HPLC, high-performance liquid chromatography; HOAc, acetic acid; IPTG, isopropyl $\beta$-D-thiogalactopyranoside; LB medium, Luria-Bertani medium; OD, optical density at indicated wavelength; PAGE, polyacrylamide gel electrophoresis; PCR, polymerase chain reaction; PMSF, phenylmethanesulfonyl fluoride; NMR, nuclear magnetic resonance; rmsd, root mean square deviation; rpm, rounds per minute; SDS, sodium dodecyl sulfate; Trx, E. coli thioredoxin. 
identicalstructural properties were proved by NMR spectroscopy as well as CD spectroscopy at various temperatures and $\mathrm{pH}$ values. Most importantly, analytical ultracentrifugation studies for protein concentrations up to $1 \mathrm{mM}$ revealed native as well as recombinant proguanylin to be monomeric in solution.

\section{MATERIALS AND METHODS}

Construction of the Expression Vector pET-32a-presproguanylin. The cDNA encoding the human prohormone proguanylin was amplified by PCR (14) using a forward primer that introduces a $B g l I I$ site and a sequence encoding a prescission proteinase cleavage site at the $5^{\prime}$ end of the gene (GGA GGA A GAT CTG GGT CTG GAA GTT CTG TTC CAG GGG CCC GTC ACC GTG CAG GAT GGA AAT TTC TCC). The reverse primer contains an NcoI site at its $5^{\prime}$ end (GGA GGA CCA TGG TTA GCA TCC GGT ACA GGC AGC GTA GG), and the PCR fragment was inserted into the T7 RNA polymerase-based expression vector pET-32a (Novagen, Madison, WI). The resulting pET-32a-pres-proguanylin is able to produce the protein proguanylin with an $\mathrm{NH}_{2}$-terminal Escherichia coli thioredoxin fusion (Trx tag; Novagen, Madison, WI). The two proteins are connected by a 46 amino acid linker containing six histidine residues, as well as a prescission proteinase cleavage site (LEVLFQ $\downarrow_{G P}$ ), resulting in the fusion protein Trx-pres-proguanylin.

Preparation of Soluble Extracts. A starter culture of 50 $\mathrm{mL}$ of LB containing $200 \mu \mathrm{g} / \mathrm{mL}$ ampicillin and $15 \mu \mathrm{g} / \mathrm{mL}$ kanamycin was inoculated with the $E$. coli strain AD494(DE3)/pET-32a-pres-proguanylin and grown overnight at 37 ${ }^{\circ} \mathrm{C}$. The starter culture was used to inoculate $1 \mathrm{~L}$ of $\mathrm{LB}$ medium (containing $200 \mu \mathrm{g} / \mathrm{mL}$ ampicillin and $15 \mu \mathrm{g} / \mathrm{mL}$ kanamycin) at an $\mathrm{OD}_{600}$ of 0.1 . Cultures were grown to an $\mathrm{OD}_{600}$ of 0.8 , and expression of the recombinant protein was induced by addition of IPTG to a final concentration of 1 $\mathrm{mM}$. The temperature was reduced to $30^{\circ} \mathrm{C}$ during protein expression. After $4 \mathrm{~h}$, cells were harvested and resuspended


$300 \mathrm{mM} \mathrm{NaCl}$ ) per gram wet weight of cells with $0.5 \mathrm{mM}$ PMSF, $0.2 \mathrm{mg} / \mathrm{mL}$ lysozyme, $0.2 \mathrm{mg} / \mathrm{mL}$ DNase I, and 2 $\mathrm{mg} / \mathrm{mL}$ benzamidine. The cells were lysed by three $30 \mathrm{~s}$ sonication steps $\left(T=4{ }^{\circ} \mathrm{C}\right.$; Labsonic U sonicator at $150 \mathrm{~W}$ intensity), followed by freezing at $-80{ }^{\circ} \mathrm{C}$ for $2 \mathrm{~h}$. After thawing, sonication was repeated, and the extract was clarified by centrifugation for $45 \mathrm{~min}$ at $40000 \mathrm{rpm}$ at $4{ }^{\circ} \mathrm{C}$ in a TFT 70.38 rotor.

Purification of Recombinant Proguanylin. The soluble extract $(50 \mathrm{~mL})$ was loaded on a $\mathrm{Co}^{2+}$-Talon superflow column (15 mL bed volume; Clontech, Palo Alto, CA) that was preequilibrated in buffer A. The column was washed with buffer $\mathrm{A}$ and buffer A containing $50 \mathrm{mM}$ imidazole, and the absorbed proteins were eluted with buffer A containing $100 \mathrm{mM}$ imidazole. Fractions containing the fusion protein (as verified by SDS-PAGE) were dialyzed against $50 \mathrm{mM}$ sodium phosphate, $\mathrm{pH} 8.0$, and $150 \mathrm{mM}$ sodium chloride to reduce the high imidazole concentrations. The protein concentration was estimated using the BCA assay (Pierce, Rockford, IL) (15).

To remove the Trx tag, the dialyzed protein solution was incubated at room temperature with prescission proteinase
(Amersham Biosciences Inc., Uppsala, Sweden) according to the manufacturer's instructions for $3 \mathrm{~h}$, cleaving the fusion protein to recombinant proguanylin containing an additional Gly and Pro residue at its $\mathrm{NH}_{2}$ terminus. The sample solution was loaded onto a $\mathrm{Co}^{2+}$-Talon superflow column $(15 \mathrm{~mL}$ bed volume) preequilibrated in buffer A. The column was washed with buffer $\mathrm{A}$, and the proguanylin-containing fractions were pooled and dialyzed against distilled water. After estimation of protein concentration, the protein solution was freeze-dried. Purified recombinant proguanylin was subjected to amino acid sequencing, mass spectrometry, RPHPLC, CZE, analytical ultracentrifugation, CD, and NMR spectroscopy.

Origin of Native Proguanylin. Native proguanylin was isolated by HPLC from a large-scale peptide sublibrary that was prepared from hemofiltrate collected from patients with chronic renal failure (29) and purified by HPLC on a Vydac C18 column (The Separations Group; $10 \times 250 \mathrm{~mm}, 5 \mu \mathrm{m}$, $300 \AA$ A; solvent A, $0.1 \%$ TFA; solvent B, $0.1 \%$ TFA in $\mathrm{MeCN} / \mathrm{H}_{2} \mathrm{O}, 4: 1$; gradient, $30-80 \%$ solvent $\mathrm{B}$ in $50 \mathrm{~min}$; flow rate, $3.5 \mathrm{~mL} / \mathrm{min}$; UV detection at $230 \mathrm{~nm}$ ). Purity and identity were checked by analytical HPLC, capillary zone electrophoresis, electrospray mass spectrometry, amino acid analysis, and Edman degradation.

Analytical HPLC and Mass Spectrometry. Analytical HPLC was carried out on a Jupiter C18 column (Phenomenex; $5 \mu \mathrm{m}, 300 \AA$ A, $1.5 \times 250 \mathrm{~mm}$; solvent A, $0.1 \%$ TFA; solvent $\mathrm{B}, 0.1 \%$ TFA in $\mathrm{MeCN} / \mathrm{H}_{2} \mathrm{O}, 4: 1$; gradient, $10-70 \%$ solvent $\mathrm{B}$ in $60 \mathrm{~min}$; flow rate, $0.2 \mathrm{~mL} / \mathrm{min}$; UV detection at $215 \mathrm{~nm}$ ). Electrospray mass spectrometric analysis was carried out on a Sciex API III (Perkin-Elmer).

Acetic Acid Cleavage of Proguanylin. Samples of native and recombinant proguanylin $(50 \mu \mathrm{g})$ were incubated in 50 $\mu \mathrm{L}$ of $1 \mathrm{M} \mathrm{HOAc}$ at $95^{\circ} \mathrm{C}$ for $0,15,30,45$, and $60 \mathrm{~min}$. The reactions were stopped by freezing with liquid nitrogen, and the samples were lyophylized. The remaining material of each sample was dissolved in $50 \mu \mathrm{L}$ of $\mathrm{H}_{2} \mathrm{O}$ and subjected to cGMP bioassay, electrospray mass spectrometry, and HPLC. For chromatography, a constant gradient from $10 \%$ to $70 \%$ solvent $\mathrm{B}$ in $60 \mathrm{~min}$ was used at a column temperature of $11^{\circ} \mathrm{C}$.

cGMP Assay. The production of intracellular cGMP upon stimulation of cultured human colon carcinoma T84 cells was evaluated after incubation of these cells with pure peptides in a concentration range between $10^{-8}$ and $10^{-6} \mathrm{M}$ and with HOAc-treated samples of proguanylin of a total concentration of $\sim 10^{-6} \mathrm{M}$ for $45 \mathrm{~min}$ in the presence of 1 $\mathrm{mM}$ isobutylmethylxanthine (9). The reaction was stopped by removal of the medium and addition of ice-cold ethanol. Subsequently, the cGMP content was measured using a specific cGMP-ELISA (IHF, Hamburg). Effects on the intracellular cGMP level were compared with those of synthetic human guanylin (15 amino acid residues, selectively introduced disulfide bonds) and $E$. coli heat-stable enterotoxin.

Capillary Zone Electrophoresis. Capillary zone electrophoresis (CZE) was carried out on a Bio-Rad CZE CE3000 system (Bio-Rad, Munich, Germany) in $100 \mathrm{mM}$ phosphate buffer with a polymer modifier ( $\mathrm{pH} 2.5$ ) [capillary, $30 \mathrm{~cm}$ $\times 50 \mu \mathrm{m}$ (uncoated); temperature, $19{ }^{\circ} \mathrm{C}$; absorbance detected at $200 \mathrm{~nm}$; run time, $15 \mathrm{~min}$ ]. 
CD Spectroscopy. Far-UV CD spectra were recorded on a Jasco J-810 spectropolarimeter (Jasco Inc., Gross-Umstadt, Germany) with $9.5 \mu \mathrm{M}$ recombinant and $3.5 \mu \mathrm{M}$ native proguanylin at room temperature (i.e., $20^{\circ} \mathrm{C}$ ), each in a 0.1 $\mathrm{cm}$ cell. Spectra were measured from 260 to $185 \mathrm{~nm}$ at 20 $\mathrm{nm} / \mathrm{min}$. To investigate a possible influence of different $\mathrm{pH}$ values on the $\mathrm{CD}$ spectra, the following buffer conditions were applied to both protein samples: $\mathrm{H}_{2} \mathrm{O}$ (i.e., $\mathrm{pH} 4.0$ ), $10 \mathrm{mM}$ potassium phosphate, $\mathrm{pH} 5.0,10 \mathrm{mM}$ potassium phosphate, $\mathrm{pH} 6.0$, and $10 \mathrm{mM}$ sodium phosphate, $\mathrm{pH}$ 7.4. The particular reference samples contained buffer without protein. Spectra were measured six times and averaged for sample and reference, respectively.

The influence of temperature on structure and refolding of recombinant and native proguanylin was investigated with samples containing $1.0 \mu \mathrm{M}$ protein concentration in $10 \mathrm{mM}$ potassium phosphate, $\mathrm{pH} 6.0$, each in a $1 \mathrm{~cm}$ cell, by recording the ellipticity at $208 \mathrm{~nm}$. Temperature was first increased and then decreased between 20 and $100{ }^{\circ} \mathrm{C}$ at a heating and cooling rate of $1{ }^{\circ} \mathrm{C} / \mathrm{min}$. Heating was controlled using a Peltier control element and a CDF-426S temperature unit (Jasco). Additionally, spectra were recorded from 260 to $190 \mathrm{~nm}$ at $20 \mathrm{~nm} / \mathrm{min}$ before heating after cooling, namely, at $20^{\circ} \mathrm{C}$, as well as at $90{ }^{\circ} \mathrm{C}$. Spectra were measured six times and averaged.

NMR Spectroscopy. The sample contained protein at concentrations of $2.4 \mathrm{mM}$ in $\mathrm{H}_{2} \mathrm{O} / \mathrm{D}_{2} \mathrm{O}$, pH 3.3 (9:1 v/v), and $1 \mathrm{mM}$ in $50 \mathrm{mM}$ potassium phosphate $\left(10 \% \mathrm{D}_{2} \mathrm{O}\right), \mathrm{pH}$ 6.0 , for native and recombinant protein, respectively. 1D NMR experiments were carried out at $20^{\circ} \mathrm{C}$ on a commercial Bruker DRX600 spectrometer equipped with triple resonance ${ }^{1} \mathrm{H} /{ }^{13} \mathrm{C} /{ }^{15} \mathrm{~N}$ probes and pulsed field gradient capabilities using standard techniques. Data processing was performed using the Ndee software package (SpinUp Inc., Dortmund, Germany) on Sun and DEC workstations.

Analytical Ultracentrifugation. Sedimentation equilibrium and velocity experiments were carried out using an Optima XL-I analytical ultracentrifuge (Beckman Coulter, Fullerton, CA), equipped with both absorbance and interference optical detection systems, using a Beckman An-60 Ti rotor with cells containing sapphire windows and either aluminum-filled epon or titanium double-sector centerpieces (path length 1.2 $\mathrm{cm}$ ) (Nanolytics $\mathrm{GmbH}$, Dallgow, Germany). Prior to centrifugation, recombinant proguanylin was purified by HPLC as described for the native protein (see above), and all samples were exhaustively dialyzed ( $>20 \mathrm{~h}$ ) into $50 \mathrm{mM}$ sodium phosphate $/ 50 \mathrm{mM}$ sodium chloride buffer, $\mathrm{pH}$ 7.4. The molar extinction coefficient at $280 \mathrm{~nm}\left(1865 \mathrm{M}^{-1} \mathrm{~cm}^{-1}\right)$, partial specific volumes $(0.737 \mathrm{l} / \mathrm{g})$, and molecular masses for both native and recombinant proguanylin (10337 and $10491 \mathrm{Da}$, respectively) were calculated on the basis of amino acid composition using the program Sednterp (16).

For the sedimentation equilibrium experiments the cells were filled with $120-130 \mu \mathrm{L}$ sample and reference (140$150 \mu \mathrm{L}$ ) solutions at loading concentrations between 0.3 and $1 \mathrm{mM}$. Sedimentation equilibrium was attained at $20 \mathrm{~h}$ at a rotor temperature of $20{ }^{\circ} \mathrm{C}$ and at a rotor speed of 25000 $\mathrm{rpm}$. Absorbance profiles were acquired at a wavelength of $280 \mathrm{~nm}$ and at radial increments of $0.003 \mathrm{~cm}$, each data point being an average of three measurements. Interferometric patterns were recorded with only water in the cell at appropriate speeds and used for correcting for radial- dependent fluctuation in Rayleigh response across the cell. Sedimentation equilibrium absorbance and interference fringe displacement data were fitted for molar mass of the solute by standard numerical analysis using the program MSEDEQI in MATLAB (kindly provided by Dr. Allen Minton, National Institutes of Health, Bethesda, MD) and Sedfit (http:// www.analyticalultracentrifugation.com). Estimates of the weight-average molar mass $\left(M_{\mathrm{r}}\right)$ were obtained from the nonlinear least-squares best fit to a single species according to the equation:

$S(r)=S\left(r_{0}\right) \exp \left[\left(\omega^{2} / 2 R T\right) M_{\mathrm{r}}(1-v \rho)\left(r^{2}-r_{0}^{2}\right)\right]+E$

$S(r)$ is the experimental observed concentration signal in absorbance or fringes at radius $r, S\left(r_{0}\right)$ is the concentration signal at the reference radius $r_{0}, \omega$ is the rotor angular velocity, $R$ is the gas constant, $T$ is the temperature, $M_{\mathrm{r}}$ is the weight average molar mass, $v$ is the partial specific volume of the solute, $\rho$ is the solvent density, and $E$ is the baseline offset.

For sedimentation velocity experiments samples (240$290 \mu \mathrm{L})$ and reference $(250-300 \mu \mathrm{L})$ solutions were loaded into cells at concentrations between 0.3 and $1 \mathrm{mM}$. The rotor temperature was equilibrated at $20^{\circ} \mathrm{C}$ in the vacuum chamber for $1-2 \mathrm{~h}$ prior to the start of the run. Experiments were conducted at $20{ }^{\circ} \mathrm{C}$ at rotor speeds of either $40000 \mathrm{rpm}$ (aluminum-filled epon centerpiece) or $60000 \mathrm{rpm}$ (titanium centerpiece). Absorbance data in continuous mode with a step size of $0.003 \mathrm{~cm}$ at a wavelength of $280 \mathrm{~nm}$ and interference fringe displacement data were collected at time intervals of either 300 or $30 \mathrm{~s}$ without averaging.

Sedimentation velocity data analysis was performed with the program Sedfit. By direct boundary modeling with distributions of Lamm equation solutions (17), the measured absorbance or interference profiles $a(r, t)$ were modeled as an integral over the differential concentration distribution $c(s)$

$$
a(r, t) \equiv \int c(s) L(s, D(s), r, t) \mathrm{d} s+\epsilon
$$

with $\epsilon$ the noise components and $L(s, D, r, t)$ the solution of the Lamm equation for an ideally sedimenting species (18) of sedimentation coefficient $s$ and diffusion coefficient $D$. The Lamm equation was solved by finite element methods on a static or moving frame of reference $(19,20)$. Analogously, the size distribution can also be calculated as a molar mass distribution, $c(m)$, where $M$ (molar mass) replaces $s$

$$
a(r, t) \equiv \int c(M) L(M, D, r, t) \mathrm{d} M+\epsilon
$$

All size distributions were solved on a radial grid of either 500 or 1000 radius values between the meniscus and bottom, a confidence level of $p=0.95$, and a resolution $N$ of 100 sedimentation coefficients between 0.2 and $10 \mathrm{~S}$ (or molar masses between 500 and $100000 \mathrm{Da}$ ). The diffusion coefficient $D$ was estimated as a function of sedimentation coefficient $s$ on the basis of the known partial specific volume of the protein and on an estimated anhydrous frictional ratio $\left(f / f_{0}\right)$ (17). The frictional ratio represents the ratio of the frictional coefficient to that of an anhydrous sphere and was estimated by treating it as a floating parameter in fitting the data. 


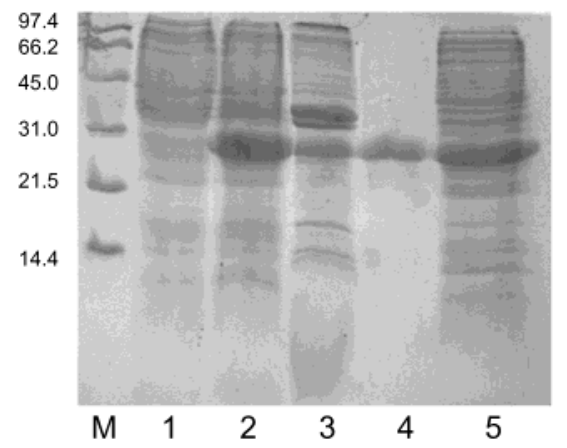

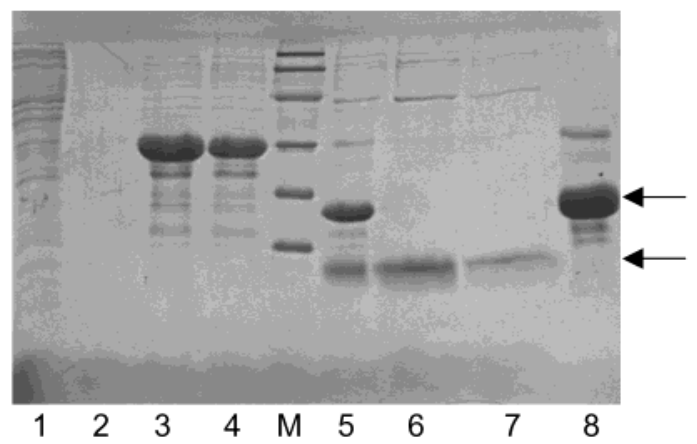

FIGURE 1: Purification of recombinant proguanylin: (a) Expression of proguanylin as a thioredoxin fusion protein in E. coli AD494(DE3). $M=$ molecular mass markers (in $\mathrm{kDa}$ ); lanes 1 and 2 are before and after induction with $1 \mathrm{mM}$ IPTG, respectively; lane 3 is the insoluble fraction of the cell lysate; lane $4+5$ is the soluble fraction of the cell lysate. (b) Purification of recombinant proguanylin from soluble extracts. First $\mathrm{Co}^{2+}$-chelating affinity chromatography: lanes 1 and 2, flow-through and washout of unbound proteins; lanes 3 and 4 , Trx-pres-proguanylin-containing fractions; $M$, molecular mass markers [as in (a)]; lane 5, after fusion protein cleavage (Trx tag and recombinant proguanylin are marked by arrows). Second $\mathrm{Co}^{2+}$-chelating affinity chromatography: lanes 6 and 7 , flow-through, i.e., recombinant proguanylin-containing fractions; lane 8 , elution of bound proteins, i.e., Trx tag, and uncleaved fusion protein.

\section{RESULTS}

Purification of Recombinant Proguanylin. The vector pET32a-pres-proguanylin was constructed to produce the human prohormone proguanylin with an $\mathrm{NH}_{2}$-terminal $E$. coli thioredoxin fusion using standard PCR techniques (13). As host strain for expression of recombinant proguanylin, $E$. coli AD494 (DE3), a trx $\mathrm{B}^{-}$mutant was used, allowing disulfide formation in the oxidative cytoplasm of this strain (21).

Expression of the Trx-fusion protein (Trx-pres-proguanylin, $254 \mathrm{aa}, 27.5 \mathrm{kDa}$ ) was induced for $4 \mathrm{~h}$ by addition of IPTG to a final concentration of $1 \mathrm{mM}$ (Figure 1a, lane 2). To avoid reduction of disulfide bridges and renaturation of denatured fusion protein from inclusion bodies, only the soluble fraction of cell lysate was used for further purification (Figure 1a, lanes 4 and 5). Trx-pres-proguanylin was purified by one-step metal-chelating affinity chromatography (22) (Figure 1b, lanes 3 and 4).

Enterokinase (EK) and factor Xa are, according to their specificity (EK, DDDDK $\downarrow$; factor Xa, IEGR $\downarrow$ ), the only commercially available proteinases to cleave fusion proteins to the desired product without additional amino acids at its $\mathrm{NH}_{2}$ terminus. Due to a high rate of nonspecific cleavage we were not able to cleave the thioredoxin domain from either fusion protein containing an EK or a factor Xa cleavage site (data not shown), requiring a modified Trxfusion protein containing a prescission cleavage site. Incubation with prescission proteinase resulted in a nearly complete cleavage of the fusion protein, observed by a strong decrease in intensity of the fusion protein band (Figure 1b, lane 5). The bands of apparently 17 and $10 \mathrm{kDa}$ correspond to Trx tag and recombinant proguanylin (Figure 1b, lane 5; bands are marked by an arrow) possessing an additional Gly and Pro residue at its $\mathrm{NH}_{2}$ terminus, compared to the native protein. A second $\mathrm{Co}^{2+}$-chelating affinity chromatography step removed the Trx tag and resulted in total of 4-6.7 mg of recombinant proguanylin with apparent homogeneity (Figure 1b, lanes 6 and 7) from $2.5 \mathrm{~g}$ of wet weight cells (1 L of culture). $\mathrm{NH}_{2}$-terminal sequencing (GPVTVQDGNFSFSLE-) validated the purified protein to be recombinant proguanylin. Additionally, the molecular mass of $10491 \mathrm{Da}$ as determined by electrospray mass spectrometry was in agreement with the calculated value.

Characterization and Disulfide Determination of Recombinant Proguanylin. Homogeneity of purified recombinant proguanylin was verified by analytical methods such as CZE and analytical HPLC (Figure 2). Even though possessing two additional amino acids at the $\mathrm{NH}_{2}$ terminus, recombinant proguanylin shows a similar elution behavior compared to the native protein when subjected to these methods (Figure 2). Furthermore, using the different methods, both proteins coeluted when injected as a mixture (Figure 2), indicating proteins with similar biophysical properties, like size, $\mathrm{p}$, and hydrophobicity.

It was shown that reliable analysis of the disulfide connectivity is possible for guanylin-(80-94), but not for the prohormone, when measured by analytical HPLC (10). Since acetic acid cleavage of a labile Asp-Pro peptide bond $(23,24)$ of proguanylin releases the bioactive $\mathrm{COOH}-$ terminal guanylin-(80-94) (25), determination of the disulfide linkage is possible (10). The two topological isomers of guanylin-(80-94) give rise to a characteristic double peak in the HPLC pattern $(5,10)$ (Figure $3 \mathrm{~b}$ ). The product of acetic acid cleavage of recombinant proguanylin also shows this characteristic profile (Figure 3a), verifying the native, biologically active, $1-3,2-4$ disulfide connectivity for the recombinant protein. The prosequence of both native and recombinant proguanylin, respectively, coelutes with the corresponding prohormone (Figure 3) (10).

cGMP Assay. Acidic acid cleavage of both native and recombinant proguanylin yielded bioactive products concerning the intracellular cGMP formation upon stimulation of human T84 cells. The cGMP level increased with the duration of the preceding HOAc treatment step, and the GCactivating potential was similar for both native and recombinant HOAc-treated proguanylin. After 30-45 min of HOAc treatment, the formation of cGMP is the same as that one induced by synthetic guanylin (Figure 4). As the correct disulfide connectivity is an absolute requirement for the biological activity of guanylin $(1,5)$, this experiment confirms the formation of the correct disulfide pattern for recombinant proguanylin. 
a
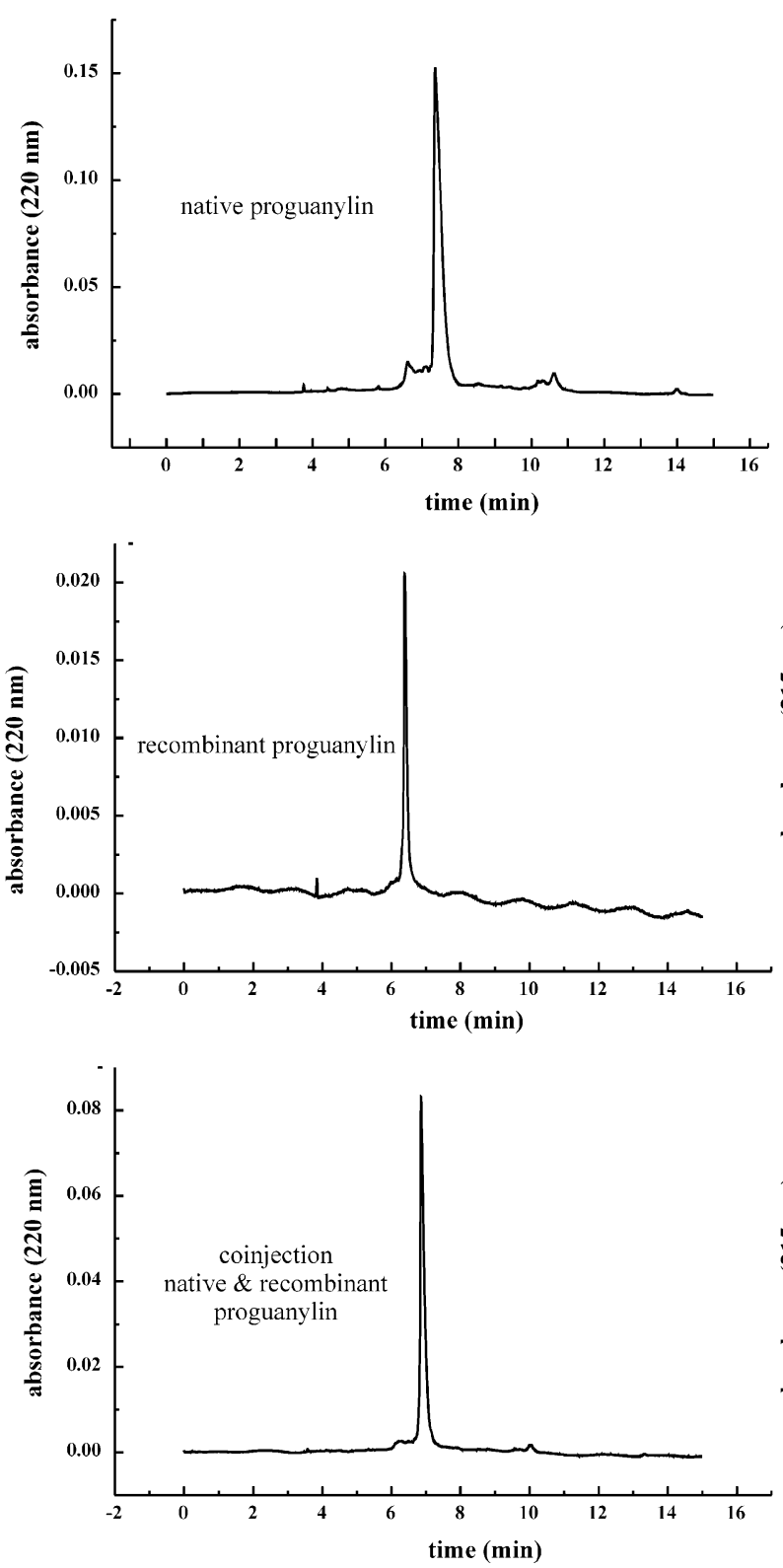

b
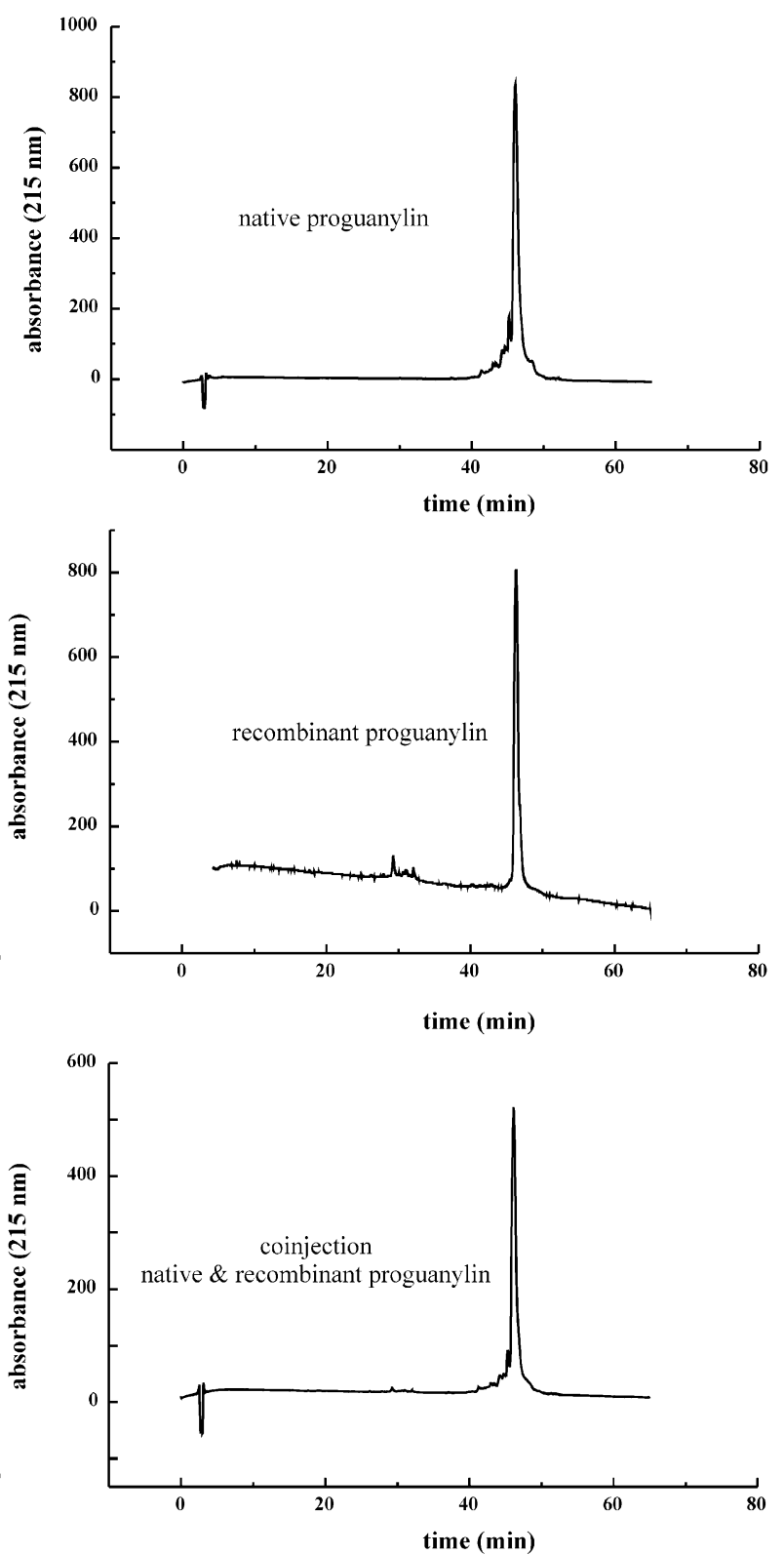

FIGURE 2: Capillary zone electrophoresis (a) and analytical HPLC (b) of recombinant and native proguanylin. Co-injection of both proteins results in one single peak, indicating similar proteins despite additional Gly-Pro residues at the $\mathrm{NH}_{2}$ terminus of recombinant proguanylin.

CD Spectroscopy. The CD spectra of native and recombinant proguanylin show a similar overall shape and are typical of well-structured proteins containing $\alpha$-helix, $\beta$-sheet portions, and unstructured regions with a broad minimum between 205 and $230 \mathrm{~nm}$ and an intense positive band at $190 \mathrm{~nm}$ (Figure 5a,b). Evaluation of the spectra resulted in an estimation of approximately $33 \% \alpha$-helix and $17 \% \beta$-sheet (26), corresponding to earlier published results (10) and to the result of secondary structure prediction (Figure 5e). When screening the literature, two quite different far-UV CD spectra of proguanylin are found: one recorded for the native (10) and another for an $\mathrm{NH}_{2}$-terminally elongated recombinant proguanylin (12). Since the sample conditions have been completely different, particularly the $\mathrm{pH}$ values, we decided to investigate whether there is a $\mathrm{pH}$ influence on the $\mathrm{CD}$ spectra of native and our recombinant protein. Only small changes could be observed for native proguanylin, which resulted in a slightly shifted zero point toward shorter wavelengths at $\mathrm{pH} 7.4$, as well as less intense positive bands at $190 \mathrm{~nm}$ for $\mathrm{pH} 6$ and 7.4 (Figure 5a). The CD spectra of recombinant proguanylin do not show any observable differences from $\mathrm{pH} 4.0$ to $\mathrm{pH} 7.4$ (Figure $5 \mathrm{~b}$ ).

An investigation of the thermal stability of both proteins showed that heating did not result in a complete loss of the CD signal (Figure $5 \mathrm{c}, \mathrm{d}$, dashed lines). At $90{ }^{\circ} \mathrm{C}$, the zero point, as well as the distinct minimum of the spectra at 205 $\mathrm{nm}$, is shifted toward shorter wavelengths compared to the spectra before heating. Additionally, a substantial decrease of the signal intensity from 205 to $230 \mathrm{~nm}$ can be seen. On recooling, similar overall shapes of the spectra, compared to those before heating, were measured but with an observable loss of total intensity and slightly shifted minima and zero points (Figure 5c,d, dotted lines).

Summarizing these observations, native and recombinant proguanylin possess identical secondary structures that are not effectively influenced by different $\mathrm{pH}$ values. Further- 

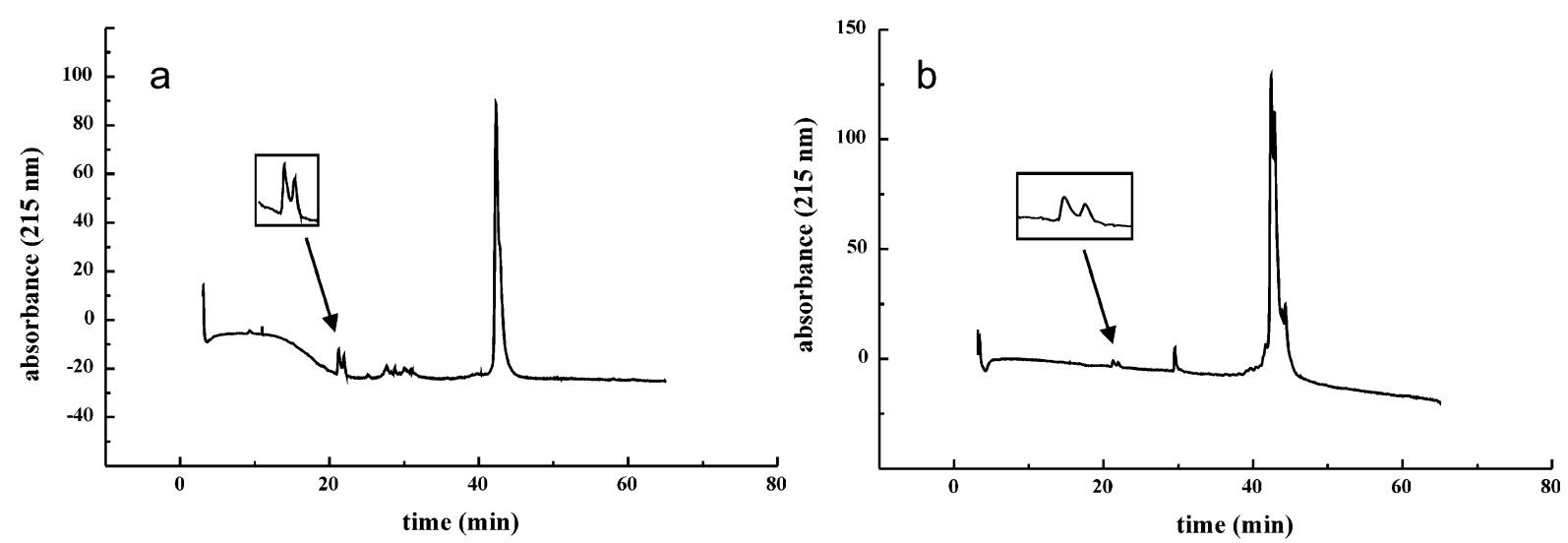

FIGURE 3: HPLC analysis of acetic acid cleavage of recombinant (a) and native (b) proguanylin. The bioactive peptide guanylin-(80-94) is released from the prohormone by cleavage of a labile Asp-Pro peptide bond. Two peaks corresponding to the rapidly interconverting topological isomers of guanylin-(80-94) can be identified (insets), verifying the correct $1-3,2-4$ disulfide connectivity for the recombinant protein.

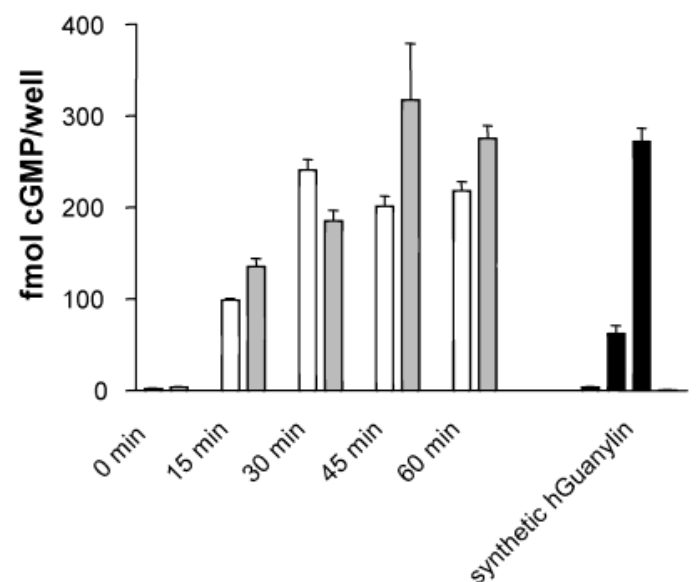

FIGURE 4: cGMP roduction of native and recombinant proguanylin after $0,15,30,45$, and $60 \mathrm{~min}$ of HOAc treatment. Starting concentration of proguanylin samples: $\sim 10^{-6} \mathrm{M}$. Bars: white, native proguanylin; gray, recombinant proguanylin; black, synthetic guanylin in the concentration range between $10^{-8}$ and $10^{-6} \mathrm{M}$.

more, for both proteins thermal denaturation is neither total nor absolutely reversible.

NMR Spectroscopy. One-dimensional ${ }^{1} \mathrm{H}$ NMR spectra were recorded for native and recombinant proguanylin, enabling comparison not only of secondary structure but also of the overall fold of both proteins. The spectra feature a high dispersion of the amide proton chemical shifts and characteristic upfield shifts of single methyl group resonances (Figure 6), suggesting well-defined structures for both proteins. The overall shapes of the spectra are highly similar, with only small differences especially concerning the resonances of protons, which are $\mathrm{pH}$ sensitive, like the resonances of the amide region, and the region from 2 to $2.5 \mathrm{ppm}$, comprising, for example, the resonances of the side chain protons of Asp and Glu. The high similarity of the spectra, especially the resonances of the two characteristic upfieldshifted methyl group resonances, as well as some characteristic downfield amide proton chemical shifts, implies not only identical secondary structures, as deduced by CD spectroscopy, but identical three-dimensional folds for native and recombinant proguanylin.

Analytical Ultracentrifugation. The association state of recombinant and native proguanylin at concentrations be- tween 0.3 and $1 \mathrm{mM}$ was characterized by sedimentation equilibrium and sedimentation velocity experiments. Analysis of the sedimentation data, at both micro- and millimolar concentrations, indicates that, under the conditions used, recombinant and native proguanylin are over $90 \%$ monomeric in solution.

Sedimentation velocity data of recombinant proguanylin at a micromolar concentration $(310 \mu \mathrm{M})$, and at $300 \mathrm{~s}$ intervals, fit very well to a continuous size distribution model (eqs 2 and 3). The best fit sedimentation profiles (Figure $7 \mathrm{a})$ are of very high quality ( $\mathrm{rmsd}=0.0056$ ), as reflected in the small and randomly distributed residuals shown in Figure $7 \mathrm{~b}$. The resulting continuous size (sedimentation coefficient, molar mass) distribution profiles, $c(s)$ and $c(M)$ (Figure 8), show the presence of a single monomeric species in solution with a sedimentation coefficient $(s)$ of $1.37 \mathrm{~S}$, apparent molar mass $(M)$ of $10020 \mathrm{Da}$, diffusion coefficient $(D)$ of $1.22 \times$ $10^{-6} \mathrm{~cm}^{2} / \mathrm{s}$, and $f / f_{0}$ of 1.22 .

An independent confirmation of the existence of a monomer in solution was obtained from sedimentation equilibrium analysis at a micromolar concentration $(310 \mu \mathrm{M})$, resulting in a molar mass $(M)$ of $9982 \mathrm{Da}$ (Figure 9). This is reasonably close to the known molecular mass of recombinant proguanylin, which is $10491 \mathrm{Da}$, based on its amino acid composition, and verified by mass spectrometry. In this fit (rmsd $=0.007)$ allowance was made for the presence of a small amount $(\sim 10 \%$ of total $)$ of a high molecular mass contaminant of up to $49 \mathrm{kDa}$. Although the presence of this high molecular mass component was not evident in the analysis of the sedimentation velocity data $(310 \mu \mathrm{M})$, better fits of sedimentation velocity and equilibrium data at high protein concentration $(1.2 \mathrm{mM})$ were obtained if this contaminant is taken into account (see below).

The data of both sedimentation velocity and equilibrium at high protein concentrations also fit to a monomeric species, although the distribution of residuals in the fits to the continuous size distribution model is poor (data not shown). In part this might be due to the onset of nonideal sedimentation at this high concentration. Also, by taking into account a small amount of a high molecular mass contaminant, $3-10 \%$ of up to $49 \mathrm{kDa}$, the fit improves substantially (data not shown). Sedimentation equilibrium analysis resulted in a calculated weight-average molecular mass of $13205 \mathrm{Da}$, which is slightly larger than that of a monomer, but 

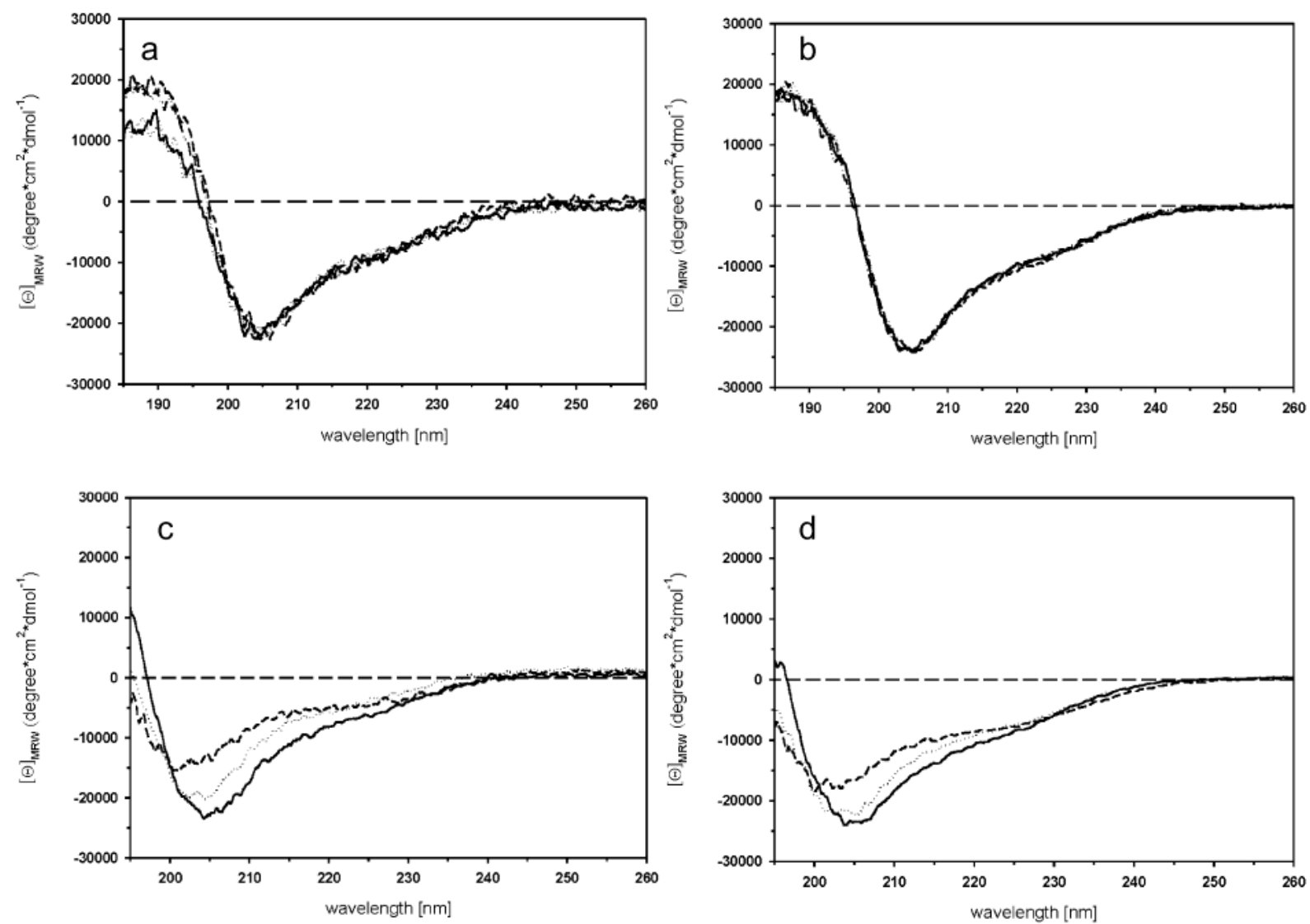

e

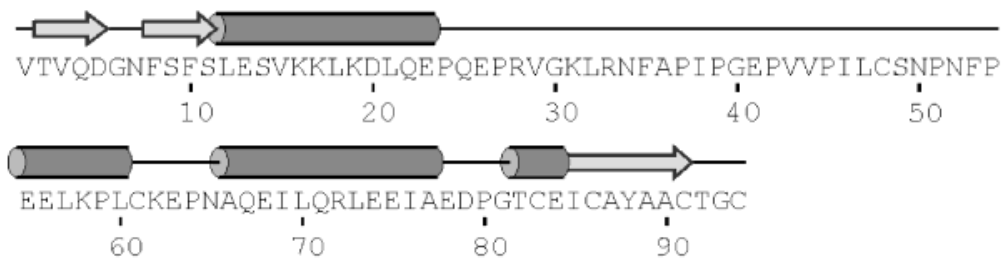

FIGURE 5: Far-UV CD spectra of native (a and c) and recombinant proguanylin (b and d). The spectra were recorded on a Jasco J-810 spectropolarimeter at room temperature with $9.5 \mu \mathrm{M}$ recombinant proguanylin and $3.5 \mu \mathrm{M}$ native proguanylin using the buffer conditions described in Materials and Methods [( $\mathrm{a}$ and $\mathrm{b})$ solid lines, $\mathrm{pH} 7.4$; dotted lines, $\mathrm{pH}$ 6.0; dash-dotted lines, $\mathrm{pH}$ 5.0; dashed lines, $\mathrm{pH} 4.0$ ]. Additionally, spectra were measured at different temperatures with protein concentrations of $1 \mu \mathrm{M}$ in $10 \mathrm{mM}$ potassium phosphate, $\mathrm{pH}$ 6.0, each in a $1 \mathrm{~cm}$ cell [ (c and d) solid lines, before heating, i.e., $20^{\circ} \mathrm{C}$; dashed lines, $90^{\circ} \mathrm{C}$; dotted lines, after recooling, i.e., $20{ }^{\circ} \mathrm{C}$ ]. (e) Secondary structure prediction of proguanylin using PSIPRED V2.2 (28).

indications are that at least $90 \%$ is monomeric recombinant proguanylin.

The sedimentation velocity data of native proguanylin at millimolar concentration also fits very well $(\mathrm{rmsd}=0.02)$ to the continuous size distribution model (Figure 10). The calculated $c(s)$ and $c(m)$ profiles show a single major peak, comprising $92 \%$ of the sample (Figure 11). Estimations of the sedimentation coefficient $(s)$ and molecular mass $(M)$ are $1.29 \mathrm{~S}$ and $10318 \mathrm{Da}$, respectively. This $M$-value is in accordance with the calculated molecular mass of $10337 \mathrm{Da}$, clearly indicating the presence of a single monomeric species. The diffusion coefficient $(D)$ was determined as $1.14 \times 10^{-6}$ $\mathrm{cm}^{2} / \mathrm{s}$ and $f / f_{0}$ as 1.35 , similar to that of recombinant proguanylin. Analysis of sedimentation velocity data at a micromolar concentration, $310 \mu \mathrm{M}$ (data not shown), is also in agreement with the presence of a monomer with $s$ - and $M$-values of $1.28 \mathrm{~S}$ and $10800 \mathrm{Da}$, respectively.
Sedimentation equilibrium analysis of native proguanylin at milli- and micromolar concentrations also supports this finding, with molecular masses $(M)$ determined as 10957 (Figure 12) and 10779 Da (data not shown), respectively. In this analysis, allowance was made for the presence of a low molecular mass contaminant, comprising no more than $10 \%$ of the total, and the $s$ - and $M$-values obtained from sedimentation velocity analysis (Figure 11) were used in the fit. The high quality of the fit ( $\mathrm{rmsd}=0.014$ ) is validated by the random distribution of the residuals (Figure 12b).

\section{DISCUSSION}

Spectroscopic Characterization of Proguanylin. The results from CD and NMR spectroscopy validate native and recombinant proguanylin to be well-structured proteins adopting identical secondary structures and three-dimensional folds. As mentioned earlier (see the Results section), far- 

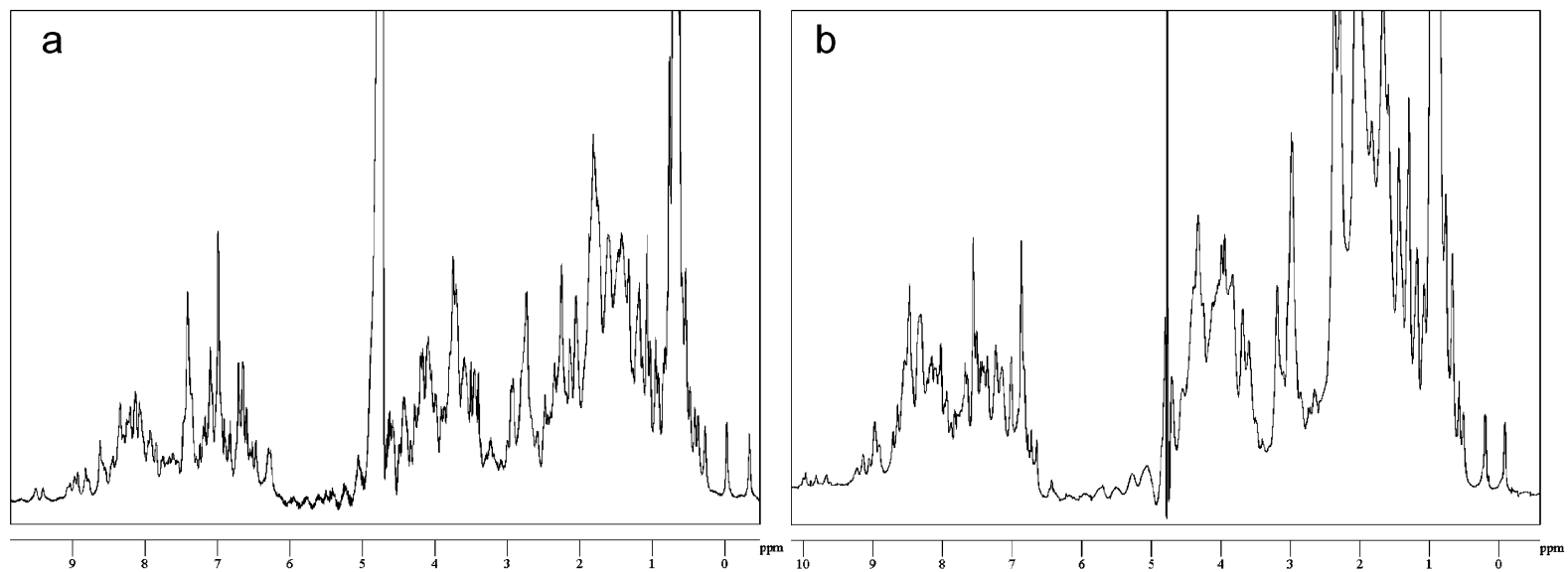

FIGURE 6: NMR spectra of native (a) and recombinant (b) proguanylin. The samples contained protein at concentrations of $2.4 \mathrm{mM}$ in $\mathrm{H}_{2} \mathrm{O} / \mathrm{D}_{2} \mathrm{O}$, pH $3.3(9: 1 \mathrm{v} / \mathrm{v})$, and $1 \mathrm{mM}$ in $50 \mathrm{mM}$ potassium phosphate $\left(10 \% \mathrm{D}_{2} \mathrm{O}\right)$, pH 6.0 at $20{ }^{\circ} \mathrm{C}$, for native and recombinant protein, respectively.

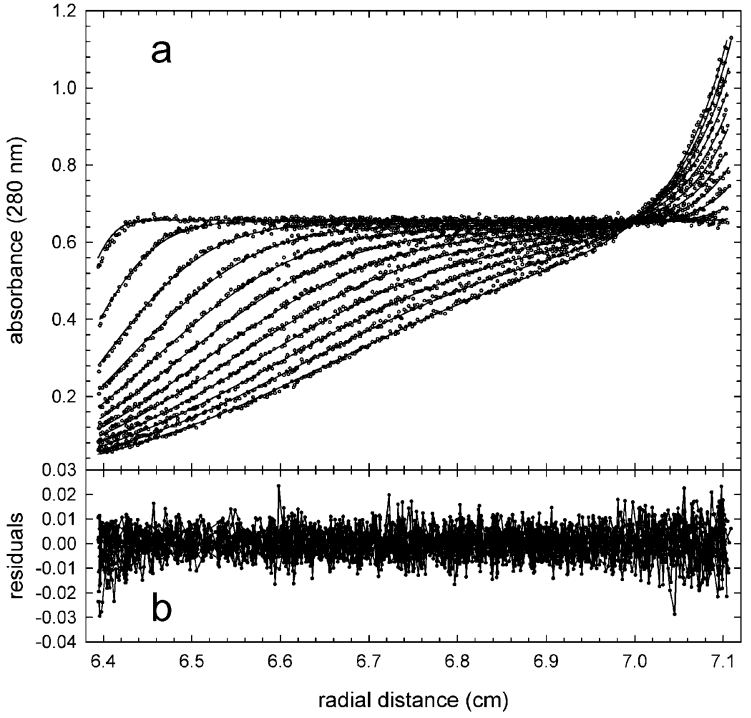

FIGURE 7: Sedimentation velocity of recombinant proguanylin. (a) Absorbance at $280 \mathrm{~nm}$ is plotted versus position from the center of rotation at time intervals of $300 \mathrm{~s}$ (dotted lines). The initial protein concentration was $310 \mu \mathrm{M}$, and centrifugation was conducted at a rotor speed of $40000 \mathrm{rpm}$ and $20^{\circ} \mathrm{C}$ in $50 \mathrm{mM}$ sodium phosphate/ $50 \mathrm{mM}$ sodium chloride, $\mathrm{pH}$ 7.4. The nonlinear least-squares best fits (solid lines) of the sedimentation velocity profiles to a continuous size (sedimentation and molar mass) distribution model according to eqs 2 and 3 (calculated for $f / f_{0}=1.22$ ) resulted in an rmsd of 0.0054 . (b) Residuals plotted as a function of radial position.

UV CD spectra of proguanylin with different overall shapes have been published $(10,12)$. Our results indicate that these differences are not due to varied $\mathrm{pH}$ and buffer conditions, although we cannot exclude the influence of the five additional $\mathrm{NH}_{2}$-terminal amino acid residues of the recombinant protein, as published by Garcia et al. (12). Since our recombinant proguanylin, which also possesses two additional amino acids at its $\mathrm{NH}_{2}$ terminus as a result of fusion protein cleavage, gives rise to $\mathrm{CD}$ and NMR spectra that are identical to the native protein (Figures 5 and 6), the obvious difference in the $\mathrm{CD}$ spectrum observed by Garcia et al. (12) is unlikely to be caused by additional residues. The differences in the CD spectra could possibly be explained by assuming the presence of a certain amount of non-native disulfide isomers.
Native and our recombinant proguanylin not only have identical secondary structures but also show identical behavior toward thermal denaturation (Figure $5 c, d$ ). Since the observed loss of signal intensity from heating was only about $40 \%$ when compared to the folded state before heating, it can be assumed that there is a significant amount of residual secondary structure. The observed shift of the zero points at $90{ }^{\circ} \mathrm{C}$, as well as the shifted distinct minimum at $205 \mathrm{~nm}$, is typical of an increased proportion of unstructured regions (26). This is due to the high temperature which causes a partial denaturation and enhanced flexibility. The measured data thus indicate a certain loss of secondary structural elements, mainly helix, with a remaining part of stable secondary structure at high temperature. In contrast to unfolding of proteins by addition of urea or guanidine hydrochloride, temperature-induced denaturation does not stabilize the unfolded state, enhancing the possibility of aggregation and precipitation of denatured proteins. This might be an explanation for thermal denaturation of proguanylin not being completely reversible (Figure 5c,d), even though precipitation after heating was not observed.

Analytical Ultracentrifugation. An essential contribution of the prosequences of guanylin and uroguanylin in the in vitro disulfide-coupled folding was previously shown (10, 11). Furthermore, unusual elution behavior in size exclusion chromatography led to the suggestion of the homologous proteins proguanylin and prouroguanylin being dimers in solution $(10,11)$. Moreover, it was suggested that dimer formation is involved in the folding pathway of prouroguanylin, with the critical protein concentration for dimerization ranging between 1 and $10 \mu \mathrm{M}$ (13). The observed elution behavior of native proguanylin on a gel filtration column was not influenced by varying the protein concentration from $1 \mu \mathrm{M}$ to $1 \mathrm{mM}$ (10), thus contradicting the above suggestion. Additionally, no variation of the oligomerization state of native proguanylin was observed in a concentration range from 0.24 to $2.4 \mathrm{mM}$ using pulsed-field gradient NMR diffusion measurements (10). As reversible oligomerization usually is concentration dependent, these results favor a monomeric state for native proguanylin. It was, nonetheless, necessary to determine if there was oligomerization, this to exclude the existence of a very tight dimer, and to examine whether the observed interaction between the $\mathrm{COOH}$ and 

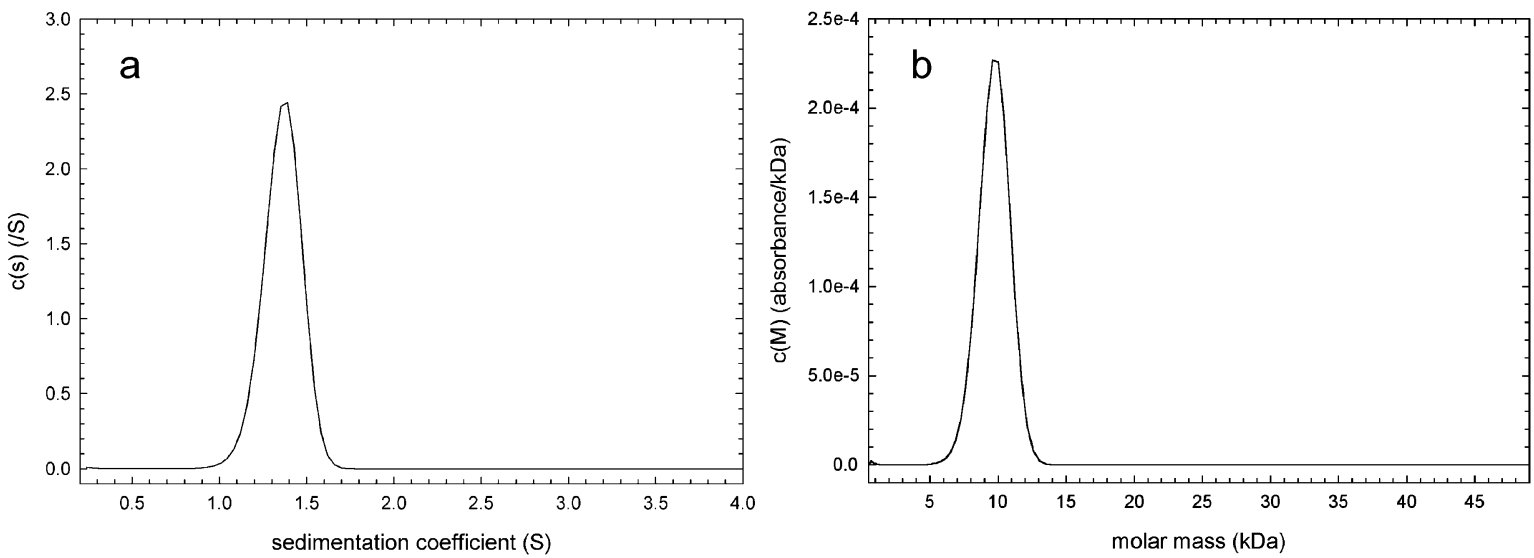

FIGURE 8: Continuous size distribution analysis of recombinant proguanylin. The calculated concentration distribution $c(s)$ is plotted versus sedimentation coefficient $(s)$ (a), and the calculated mass distribution $c(M)$ is plotted versus molar mass $(M)$ (b). Experiments were conducted at an initial protein concentration of $310 \mu \mathrm{M}$ in $50 \mathrm{mM}$ sodium phosphate $/ 50 \mathrm{mM}$ sodium chloride, $\mathrm{pH} 7.4$ at $20^{\circ} \mathrm{C}$, rotor speed of 40000 $\mathrm{rpm}$, and data were collected at time intervals of $300 \mathrm{~s}$. In both cases distributions were calculated with maximum entropy regularization at confidence levels of $p=0.95, f / f_{0}$ at 1.22 , and at a resolution of sedimentation coefficients or molar masses of $n=100$.

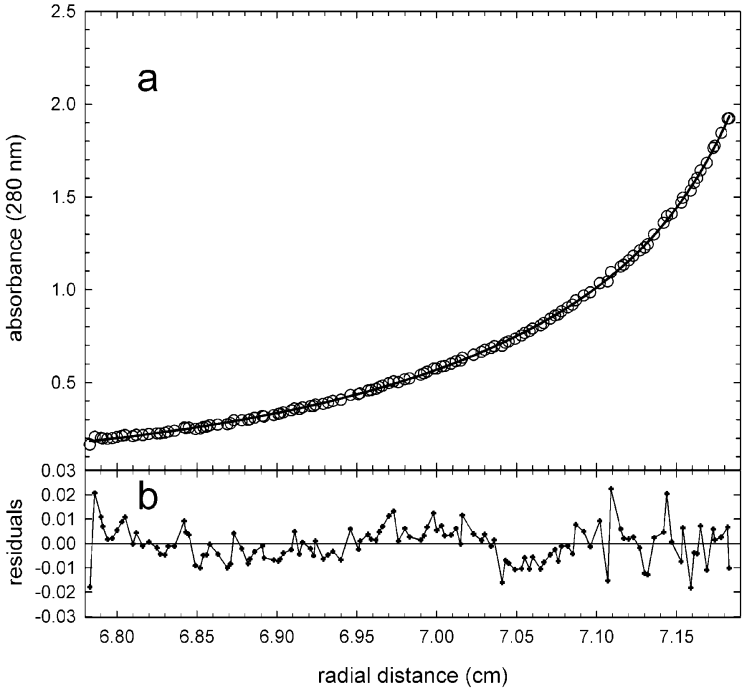

FIGURE 9: Sedimentation equilibrium of recombinant proguanylin. (a) Absorbance at $280 \mathrm{~nm}$ at equilibrium is plotted versus the distance from the axis of rotation for recombinant proguanylin at an initial protein concentration of $310 \mu \mathrm{M}$ (open circles). Samples in $50 \mathrm{mM}$ sodium phosphate $/ 50 \mathrm{mM}$ sodium chloride, $\mathrm{pH} 7.4$, were centrifuged for at least $20 \mathrm{~h}$ at $25000 \mathrm{rpm}$ and $20^{\circ} \mathrm{C}$. The solid line represents the nonlinear least-squares best fit to the data to a single monomeric species (eq 1). (b) Residuals plotted as a function of radial position.

$\mathrm{NH}_{2}$ terminus of proguanylin (10) is of an inter- or intramolecular nature. As size exclusion chromatography is not very reliable in determination of molecular mass and the oligomerization state of proteins, we decided to employ highly accurate analytical ultracentrifugation studies on native and recombinant proguanylin. In this we used new methods of analysis of sedimentation velocity data that take into account the effects of diffusion $(20,27)$.

The sedimentation velocity profiles at all concentrations of both native and recombinant proguanylin were consistent with the presence of a monomeric species. Analyses of all sedimentation equilibrium data corroborate this finding. Even at the millimolar range, native proguanylin still exists as a monomer under the solution conditions employed. For recombinant proguanylin, however, the results of sedimentation velocity data at high concentration and sedimentation equilibrium data at both concentrations are more ambiguous.

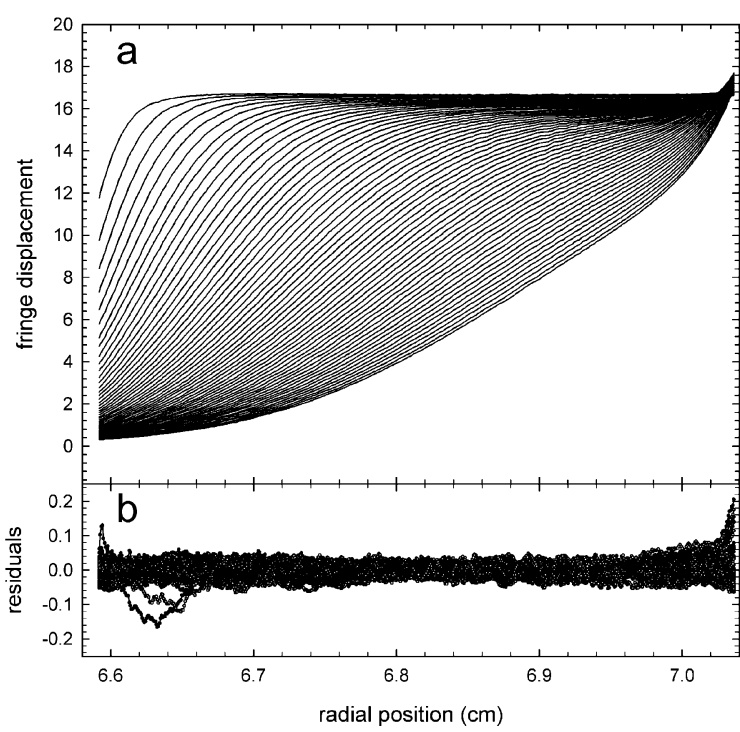

FIGURE 10: Sedimentation velocity of native proguanylin. (a) Fringe displacements are plotted versus position from the center of rotation at time intervals of $30 \mathrm{~s}$. A total of 300 scans was used in the analysis. For clarity every fifth scan is shown. The initial protein concentration was $1.0 \mathrm{mM}$, and centrifugation was conducted at a rotor speed of $60000 \mathrm{rpm}$ and $20^{\circ} \mathrm{C}$ in $50 \mathrm{mM}$ sodium phosphate/ $50 \mathrm{mM}$ sodium chloride, $\mathrm{pH}$ 7.4. The sedimentation velocity profiles were fitted to a continuous size (sedimentation and molar mass) distribution model according to eqs 2 and 3 . The rmsd of the fit is 0.02 . (b) Residuals plotted as a function of radial position.

The fits worsen if a small amount of dimer is taken into account, while they improve substantially when allowing for the presence of a higher molecular mass species, comprising no more than approximately $10 \%$ of the total (i.e., at least $90 \%$ is monomeric recombinant proguanylin under the given conditions).

The finding that this high molecular mass species showed no relative increase with an increasing concentration of protein, and the fact that this high molecular mass species was not detected in the native proguanylin sample, suggests it is a contaminant rather than an oligomer of proguanylin. Also, a reversible association between the monomer and this compound of undetermined nature is very unlikely. The results of the analysis of the sedimentation data of both recombinant and native proguanylin thus indicate that these 

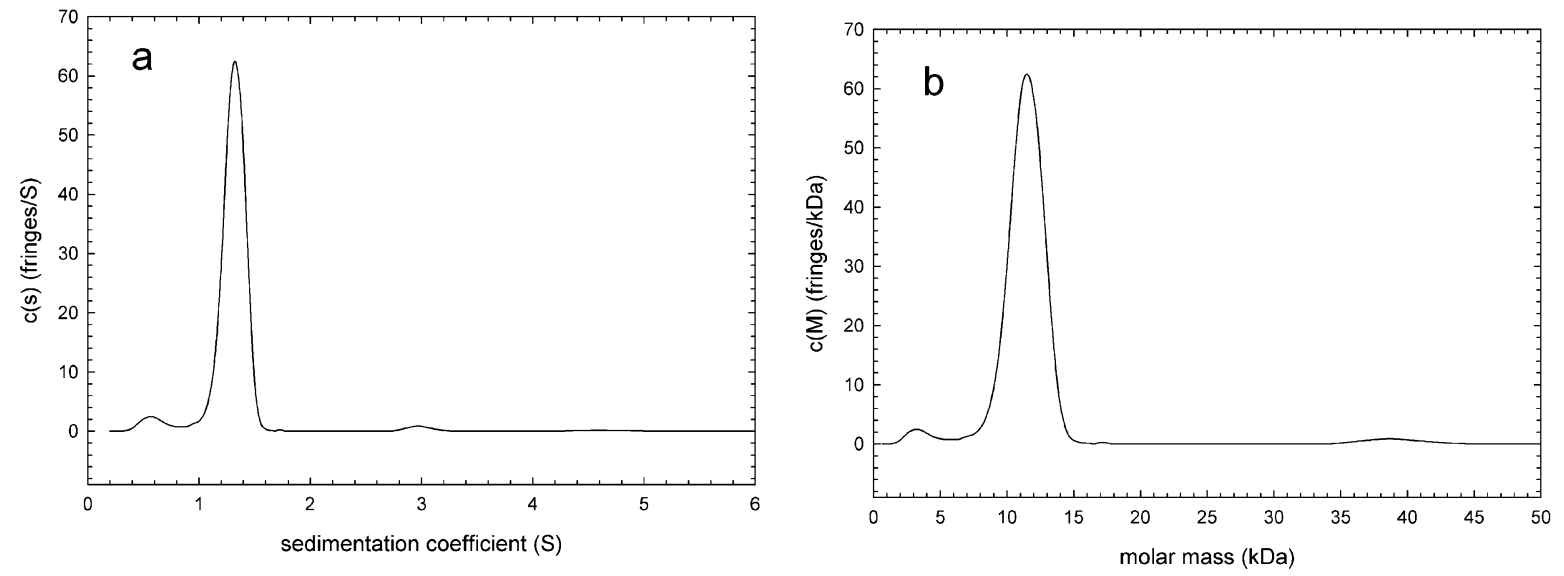

FIGURE 11: Continuous size distribution analysis of native proguanylin. (a) Calculated $c(s)$ is plotted versus sedimentation coefficient ( $s$ ), and calculated $c(M)$ is plotted versus molar mass $(M)(\mathrm{b})$. Experiments were conducted at an initial protein concentration of $1.0 \mathrm{mM}$ in 50 $\mathrm{mM}$ sodium phosphate $/ 50 \mathrm{mM}$ sodium chloride, $\mathrm{pH} 7.4$ at $20^{\circ} \mathrm{C}$, rotor speed of $60000 \mathrm{rpm}$, and data were collected at time intervals of $30 \mathrm{~s}$. In both cases the $f / f_{0}$ was 1.37 , with maximum entropy regularization at confidence levels of $p=0.95$ and at a resolution of sedimentation coefficients or molar masses of $n=100$.

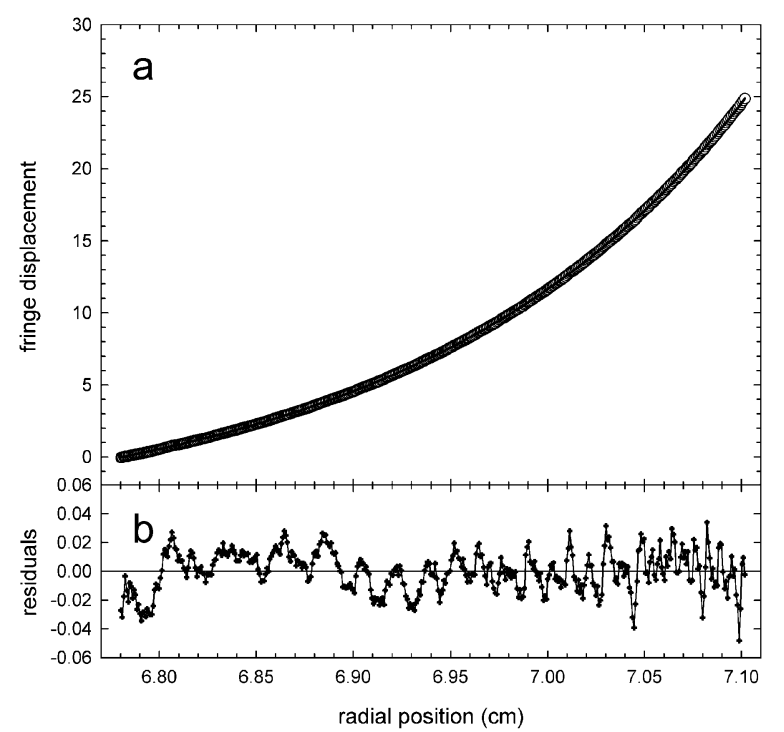

FIGURE 12: Sedimentation equilibrium of native proguanylin. (a) Fringe displacement data at equilibrium are plotted versus the distance from the axis of rotation for native proguanylin at an initial protein concentration of $1.0 \mathrm{mM}$ (open circles). Samples in $50 \mathrm{mM}$ sodium phosphate $/ 50 \mathrm{mM}$ sodium chloride, $\mathrm{pH} 7.4$, were centrifuged for at least $40 \mathrm{~h}$ at $25000 \mathrm{rpm}$ and $20{ }^{\circ} \mathrm{C}$. The solid line represents the nonlinear least-squares best fit of the data to a single monomeric species. Allowance was made for the presence $(\sim 10 \%$ of total) of a low molecular mass contaminant as observed previously (Figure 11). The rmsd of the fit is 0.014. (b) Residuals plotted as a function of radial position.

proteins do not self-associate under the given solution conditions.

Taken together, our results confute former suggestions of proguanylin being a dimer in solution (13), as ultracentrifugation measurements resulted in monomeric proguanylin at millimolar concentrations. In consideration of an unchanged oligomerization state from 0.24 to $2.4 \mathrm{mM}(10)$, our results verify a monomeric protein even at this high concentration. The observed close proximity between the termini of proguanylin is, thus, unequivocally due to intramolecular interactions. In addition, this work presents a new expression system for the recombinant production of proguanylin with its native disulfide connectivity and threedimensional fold, as deduced from comparison with native proguanylin isolated from human blood filtrate. This expression system is a prerequisite for further functional and structural studies.

\section{ACKNOWLEDGMENT}

We are grateful to Prof. Dr. Paul Rösch (Universität Bayreuth) for excellent support, and the excellent technical assistance of Blanka Karasiewicz is gratefully acknowledged. We thank Dr. Allen Minton (NIH) for critical reading of the manuscript.

\section{REFERENCES}

1. Currie, M. G., Fok, K. F., Kato, J., Moore, R. J., Hamra, F. K., Duffin, K. L., and Smith, C. E. (1992) Guanylin: an endogenous activator of intestinal guanylate cyclase, Proc. Natl. Acad. Sci. U.S.A. 89, 947-951.

2. Forte, L. R. (1999) Guanylin regulatory peptides: structures, biological activities mediated by cyclic GMP and pathobiology, Regul. Pept. 81, 25-39.

3. Chao, A. C., de Sauvage, F. J., Dong, Y. J., Wagner, J. A., Goeddel, D. V., and Gardner, P. (1994) Activation of intestinal CFTR $\mathrm{Cl}^{-}$channel by heat-stable enterotoxin and guanylin via cAMP-dependent protein kinase, EMBO J. 13, 1065-1072.

4. Forte, L. R., Freeman, R. H., Krause, W. J., and London, R. M. (1999) Guanylin peptides: cyclic GMP signaling mechanisms, Braz. J. Med. Biol. Res. 32, 1329-1336.

5. Klodt, J., Kuhn, M., Marx, U. C., Martin, S., Rösch, P., Forssmann, W. G., and Adermann, K. (1997) Synthesis, biological activity and isomerism of guanylate cyclase $\mathrm{C}$-activating peptides guanylin and uroguanylin, J. Pept. Res. 50, 222-230.

6. Skelton, N. J., Garcia, K. C., Goeddel, D. V., Quan, C., and Burnier, J. P. (1994) Determination of the solution structure of the peptide hormone guanylin: observation of a novel form of topological stereoisomerism, Biochemistry 33, 13581-13592.

7. Schulz, A., Escher, S., Marx, U. C., Meyer, M., Rösch, P., Forssmann, W. G., and Adermann, K. (1998) Carboxy-terminal extension stabilizes the topological stereoisomers of guanylin, $J$. Pept. Res. 52, 518-525.

8. de Sauvage, F. J., Keshav, S., Kuang, W. J., Gillett, N., Henzel, W., and Goeddel, D. V. (1992) Precursor structure, expression, and tissue distribution of human guanylin, Proc. Natl. Acad. Sci. U.S.A. 89, 9089-9093.

9. Kuhn, M., Raida, M., Adermann, K., Schulz-Knappe, P., Gerzer, R., Heim, J. M., and Forssmann, W. G. (1993) The circulating bioactive form of human guanylin is a high molecular weight peptide (10.3 kDa), FEBS Lett. 318, 205-209.

10. Schulz, A., Marx, U. C., Hidaka, Y., Shimonishi, Y., Rösch, P., Forssmann, W. G., and Adermann, K. (1999) Role of the prosequence of guanylin, Protein Sci. 8, 1850-1859. 
11. Hidaka, Y., Ohno, M., Hemmasi, B., Hill, O., Forssmann, W. G., and Shimonishi, Y. (1998) In vitro disulfide-coupled folding of guanylyl cyclase-activating peptide and its precursor protein, Biochemistry 37, 8498-8507.

12. Garcia, K. C., de Sauvage, F. J., Struble, M., Henzel, W., Reilly, D., and Goeddel, D. V. (1993) Processing and characterization of human proguanylin expressed in Escherichia coli, J. Biol. Chem. 268, 22397-22401.

13. Hidaka, Y., Shimono, C., Ohno, M., Okumura, N., Adermann, K., Forssmann, W. G., and Shimonishi, Y. (2000) Dual function of the propeptide of prouroguanylin in the folding of the mature peptide: disulfide-coupled folding and dimerization, J. Biol. Chem. $275,25155-25162$.

14. Ausubel, F. M., Brent, R., Kingston, R. E., Moore, D. D., Seidman, J. G., Smith, J. A., and Struhl, K. (1999) Current protocols in molecular biology, unit 15.1, Vol. 3, John Wiley \& Sons, New York.

15. Smith, P. K., Krohn, R. I., Hermanson, G. T., Mallia, A. K., Gartner, F. H., Provenzano, M. D., Fujimoto, E. K., Goeke, N. M., Olson, B. J., and Klenk, D. C. (1985) Measurement of protein using bicinchoninic acid, Anal. Biochem. 150, 76-85.

16. Laue, T. M., Shah, B. D., Ridgeway, T. M., and Pelletier, S. L. (1992) Analytical Ultracentrifugation in Biochemistry and Polymer Science, pp 90-125, The Royal Society of Chemistry, Cambridge, U.K.

17. Schuck, P. (2000) Size-distribution analysis of macromolecules by sedimentation velocity ultracentrifugation and lamm equation modeling, Biophys. J. 78, 1606-1619.

18. Lamm, O. (1929) Die Differentialgleichung der Ultrazentrifugierung, Ark. Mater. Astr. Fys. 21, 1-4.

19. Claverie, J. M. (1976) Sedimentation of generalized systems of interacting particles. III. Concentration-dependent sedimentation and extension to other transport methods, Biopolymers 15, 843857.
20. Schuck, P. (1998) Sedimentation analysis of noninteracting and self-associating solutes using numerical solutions to the Lamm equation, Biophys. J. 75, 1503-1512.

21. Derman, A. I., Prinz, W. A., Belin, D., and Beckwith, J. (1993) Mutations that allow disulfide bond formation in the cytoplasm of Escherichia coli, Science 262, 744-747.

22. Porath, J. (1992) Immobilized metal ion affinity chromatography, Protein Expression Purif. 3, 263-281.

23. Kowit, J. D., and Maloney, J. (1982) Protein cleavage by boiling in sodium dodecyl sulfate prior to electrophoresis, Anal. Biochem. $123,86-93$.

24. Rittenhouse, J., and Marcus, F. (1984) Peptide mapping by polyacrylamide gel electrophoresis after cleavage at aspartyl-prolyl peptide bonds in sodium dodecyl sulfate-containing buffers, Anal. Biochem. 138, 442-448.

25. Schulz, S., Chrisman, T. D., and Garbers, D. L. (1992) Cloning and expression of guanylin. Its existence in various mammalian tissues, J. Biol. Chem. 267, 16019-16021.

26. Greenfield, N., and Fasman, G. D. (1969) Computed circular dichroism spectra for the evaluation of protein conformation, Biochemistry 8, 4108-4116.

27. Schuck, P., Perugini, M. A., Gonzales, N. R., Howlett, G. J., and Schubert, D. (2002) Size-distribution analysis of proteins by analytical ultracentrifugation: strategies and application to model systems,Biophys. J. 82, 1096-1111.

28. Jones, D. T. (1999) Protein secondary structure prediction based on position-specific scoring matrices, J. Mol. Biol. 292, 195202.

29. Schrader, M., Jürgens, M., Hess, R., Schulz-Knappe, P., Raida, M., and Forssmann, W.-G. (1997) Matrix-assisted laser desorption/ ionisation mass spectrometry guided purification of human guanylin from blood ultrafiltrate, J. Chromatogr. A 776, 139-145.

BI026434J 